\title{
REVEALING AN UNKNOWN MUSEUM AND ITS COLLECTION USING DIGITAL TOOLS: THE PALAZZO DI GIUSTIZIA IN MILAN
}

\author{
A. Santoro, L. Barazzetti, V. Pracchi \\ Dept. of Architecture, Built environment and Construction engineering (ABC) \\ Politecnico di Milano, Piazza Leonardo da Vinci 32, Milan, Italy \\ angelica.santoro@mail.polimi.it, (luigi.barazzetti, valeria.pracchi)@polimi.it
}

KEY WORDS: Cataloguing, Conservation, Data sharing, Digital tools, Dissemination, Information, Recording tools

\begin{abstract}
:
The paper presents the generation of an interactive cataloging system for the Courthouse of Milan (Palazzo di Giustizia) and more than one hundred artworks stored in the building. The courthouse is an "unknown museum" in the city and represents a masterpiece of the architectural and figurative culture in the '30s. The online system developed in the project aims at solving a twofold task. First, it must present the "unknown museum" to citizens through a simple and effective online website. Second, it must serve as a repository for technical information not available to the public and only limited to the specialists in conservation. This second section includes catalog forms produced according to specific national standards for artworks, which require a variety of information such as size, material, artist, state of conservation, and description of previous restorations and interventions. The catalog, supported by the development of a preventive conservation plan, meets the need to identify all artworks and their conditions, planning interventions, and keeping a record of restoration activities.
\end{abstract}

\section{INTRODUCTION}

\subsection{Overview of the work}

The work described in the paper is related to the development of an online system accessible through a website (https://scoprimipalazzodigiustizia.com/), which can describe on several levels the Courthouse of Milan (Palazzo di Giustizia, Fig.1) and the artworks in the building. In fact, the courthouse can be considered an "unknown museum" in Milan and a masterpiece of the architectural and figurative culture of the '30s. In those years, Marcello Piacentini, one of the most famous architects, designs a building that constitutes a landmark for the city. Piacentini works in collaboration with more than 50 famous artists at the national level (including Martini, Fontana, Sironi, and Carrà) to interpret the concept of justice in the years of the fascist regime, following the artistic influences of the period with a revival of wall decorations in public buildings.

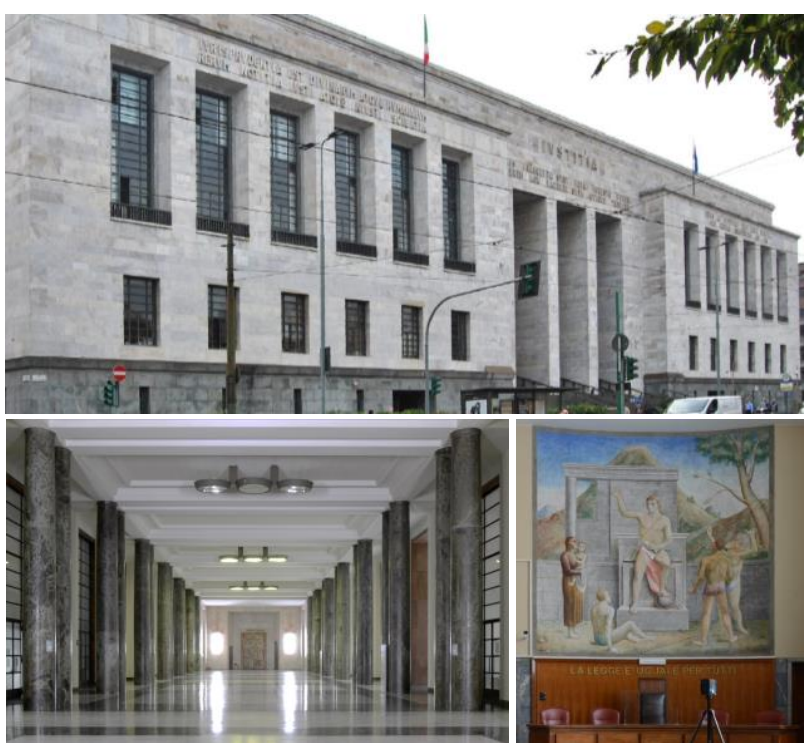

Figure 1. The Courthouse of Milan.
The online system was developed in the frameworks of a master thesis entitled "Un museo sconosciuto: il Palazzo di Giustizia di Milano. Uno strumento per la valorizzazione e la conservazione preventiva e programmata delle opere d'arte" (Santoro, 2021). The work has two main objectives:

- $\quad$ it must present the "unknown museum" through a simple and effective online website;

- $\quad$ it must serve as a repository able to host technical information for the conservation specialists.

The digital solution must therefore consider instruments and methods to share a huge amount of data in a simple and accessible way for everyone, whereas more technical data are available for a specialist audience.

\subsection{Main objective of the work}

The work started considering some problems related to particularly vulnerable artworks. 109 artworks were identified, including different bas-reliefs, some mosaics, and wall paintings (mainly frescoes). The last ones were created by the artist with the purpose to reuse the mural techniques of medieval and renaissance artworks of the Italian tradition. Their creation was carried out with a lack of experience in the technique and some experimental materials. For these reasons, some layers quickly deteriorated, making it necessary to restore most of them (Fig. 2 and 3).

Apart from the restoration work, an additional requirement was the creation of a clear and complete catalog of the artworks to make aware conservation institutions and the Palazzo's managers of the current conditions. The first operation, as agreed with the managers of the Palace, was to catalog the artworks and build a digital repository aimed at their management and maintenance. Such a catalog must be continuously updated and must track change and future interventions on the artworks, starting from simple cleaning up to major restoration. 


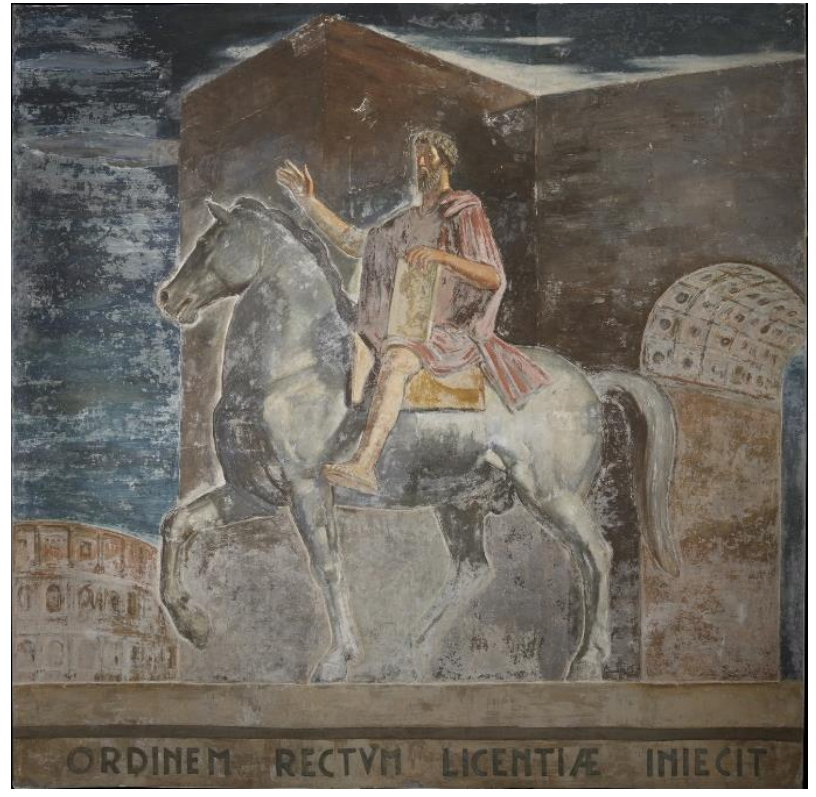

Fig 2. Ottavio Steffenini, Marco Aurelio a cavallo, 1937, 4,80x4,90 m, before restoration as described in Siena (2017).

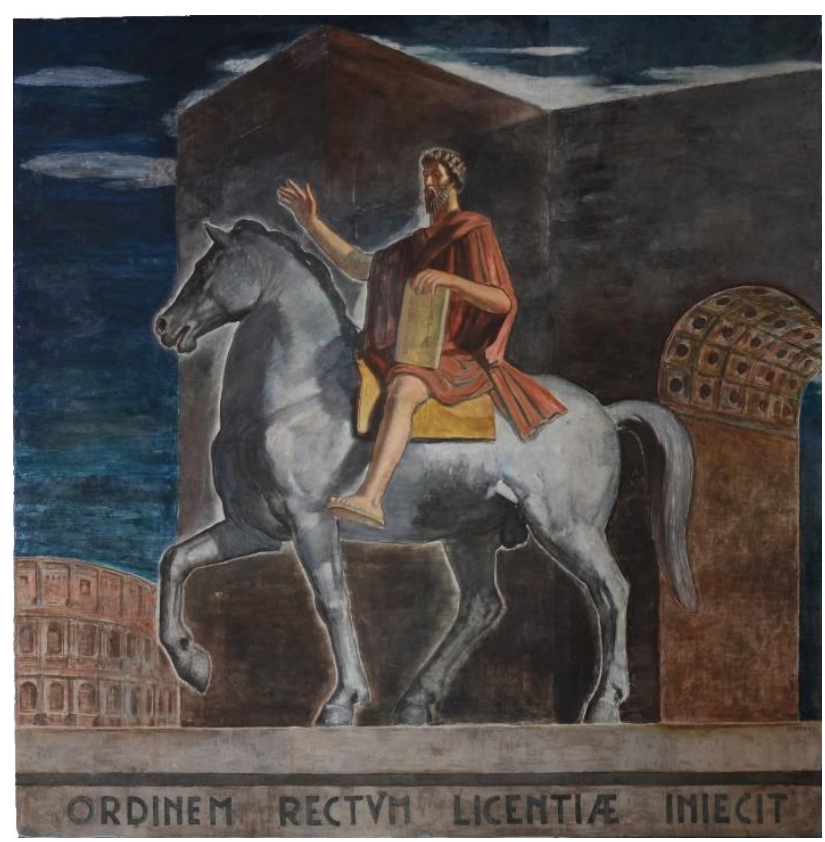

Fig 3. Ottavio Steffenini, Marco Aurelio a cavallo, as it appears today after restoration.

This new digital instrument offered the opportunity to create an additional level dedicated to the dissemination of the Palace as a museum. Nowadays, the Palace is known only for its administrative function. The building does not have great artistic and architectural fame. It is known only for its judicial function and its history is deeply linked to a specific period of Italian history and politics: the years of the fascist regime.

\section{WORKFLOW OF THE STUDY}

\subsection{Research}

The work required an initial phase of study and research. Until now, studies conducted on the courthouse and the artworks are limited and with a low level of detail. One of the reasons is related to the lack of recognition of this place as a museum, which is primarily due to the judicial function of the Palace. At the same time, there is strong link connecting the history of the building to the fascist ideology.

The study of the published sources immediately revealed the need to search for documents of the period of the construction. The available studies are mainly sectoral and investigates only some of the artworks as creations of famous artists, mainly analyzed separately from the context and the general conception of the project.

The building, with its huge size (it occupies an area of 40,000 $\mathrm{m}^{2}$ with 5 floors) was designed by Piacentini with the ambition to create a "total artwork". Piacentini took care of every aspect: from the internal distribution of spaces to the choice of different systems, coverings, doors, windows, and furniture, culminating with the decorative project and the placement of every artworks and the type of technique required according to the space, assigning the different themes from which the artists had to choose the subjects of their works (Fig. 4-7). The architect's idea was to create a decorative cycle, like those of great medieval and renaissance buildings, notwithstanding the works do not follow a continuous narrative and includes the repetition of some subjects.

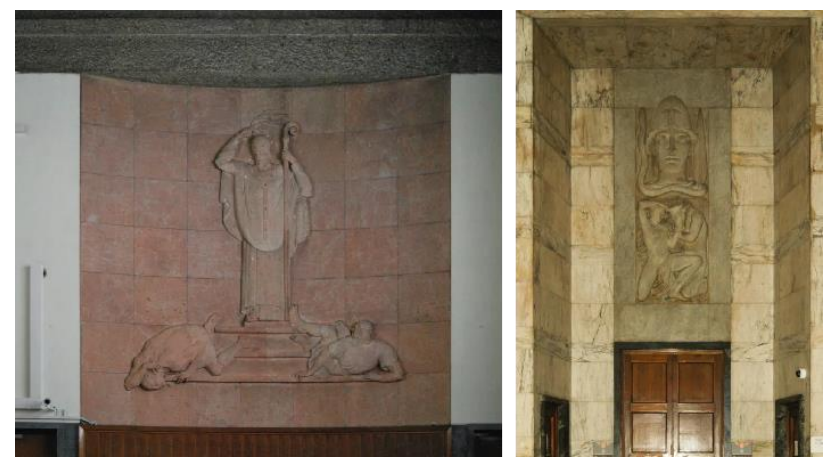

Fig. 4 and 5. Bas-relief for the plan dedicated to criminal trials. On the left inside a courtroom, on the right in the ambulatory.
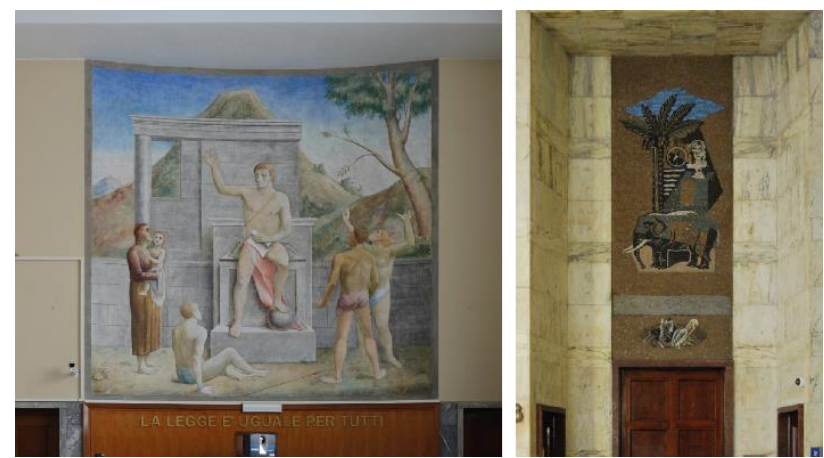

Fig 6 and 7. Two-dimensional artworks for the floor dedicated to civil trials. On the left one of the wall paintings placed inside the courtrooms, on the right one of the mosaics in the ambulatory.

As mentioned, what it is still missing is an overall vision that can relate all the different aspects considering them linked and contextualized in a wider framework, i.e. as inseparable from the architectural project. It was therefore necessary to deepen all aspects starting from the transformation of the neighborhood during the construction of the Palace, the relationship with historical and political aspects, and the iconographic study of the artworks. 


\subsection{On-site reconnaissance}

A large part of the research was carried out on site. The lack of a clear overview of the artworks (number, location, subjects, conservation status) required an on-site inspection of the spaces to verify the presence and the condition of artworks (Fig. 8). The difficult access for same spaces (especially the courtrooms) for the constant and continuous judicial activity constituted a limitation. Although it was possible to visit most spaces, it was impossible to complete the entire survey.

In addition, there were additional issues in the creation of a reliable list of artworks based on existing documents. Different sources reported different numbers, for instance, 111 in "Popolo d'Italia" (1939), 114 in a letter by Piacentini (1939), 140 in "Architettura" (1941). In some cases, the number of artworks was not specifically referring to the works commissioned or effectively created.

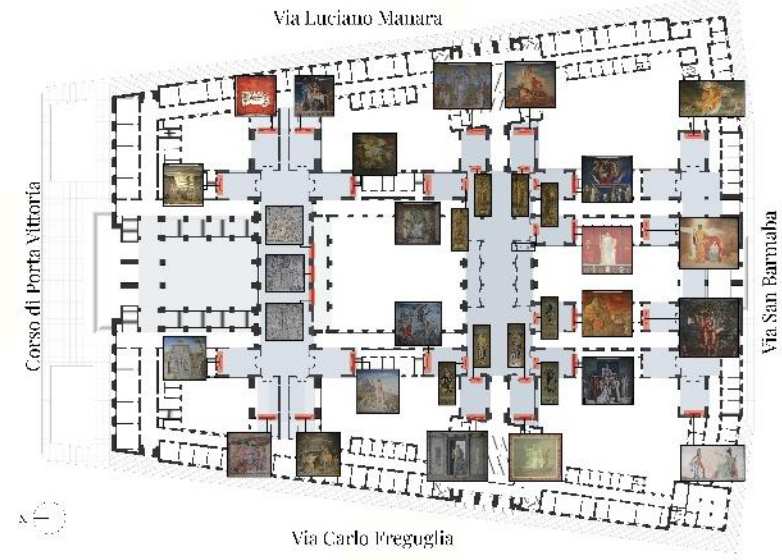

Fig 8. Identification of the artworks, third floor.

Even before the conclusion of the Palace, some artworks underwent several criticisms for political reasons. It was requested the demolition of some of them - just completed - due to the presence of nudes or biblical subjects related to the people of Israel and therefore condemned by the 1938 racial laws. Some artworks were only temporarily hidden, but for the same reasons, some were never completed.

With the end of the war the Italian political situation changed radically, and the consequences of involved fascist works, including the Palace of Justice, causing censorship and therefore the total or partial demolition of many artworks because of the presence of an iconography linked to the regime (Fig. 9).

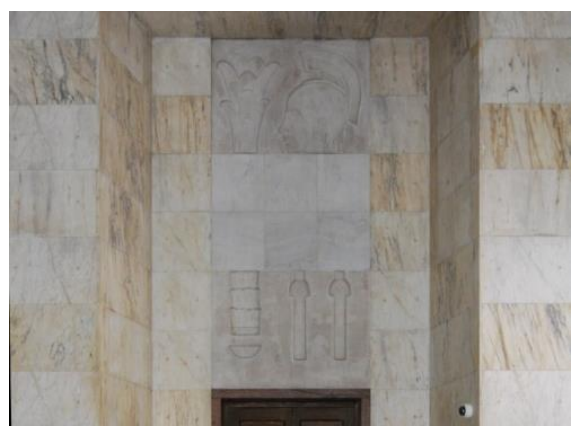

Fig 9. One of the censored artworks, which are therefore incomplete, by Carlo Pini.

\section{REPOSITORY DEVELOPMENT}

\subsection{Cataloging}

The purpose of the proposed digital tool is to respond to the need for conservation by creating a database able to track all the operations carried out in the past as well as future maintenance and restoration works, from regular cleaning operations to major interventions.

The catalog was created following the national criteria of the Central Institute for Cataloguing and Documentation (Istituto Centrale per il Catalogo e la Documentazione). It was fundamental to work in agreement with the Soprintendenza (the Italian ministerial body dealing with heritage protection) and executing the cataloging campaign using a formal and institutionally recognized process.

\subsection{Preventive maintenance}

One of the missing information is related to future interventions. For this work, both a plan for planned conservation and records for conservators must be implemented. The maintenance plan for the Palace of Justice was set up for 10 years subdivided based on the types of works, the equipment needed according to the available space, and differentiating between annual or less frequent operations.

The new forms that the restorers will have to fill in for each intervention were set up for each floor of the Palace to facilitate the operations.

\section{DIGITAL RECORDING OF THE ARTWORKS}

An important part of the work was the digital modeling of the artworks. The purpose of the digital survey was not only their documentation, but also the production of metric records necessary for specific operations such as the calculation of surfaces requiring restoration works, or the identification and mapping of decays phenomena.

The virtual models were also published on the website so that they are freely accessible and navigable. The type of the artworks can be divided into four groups:

- $\quad$ mosaics on flat surfaces (e.g. Fig. 10);

- $\quad$ wall paintings on curved surfaces;

- bas-reliefs on flat or curved surfaces;

- $\quad$ statues.

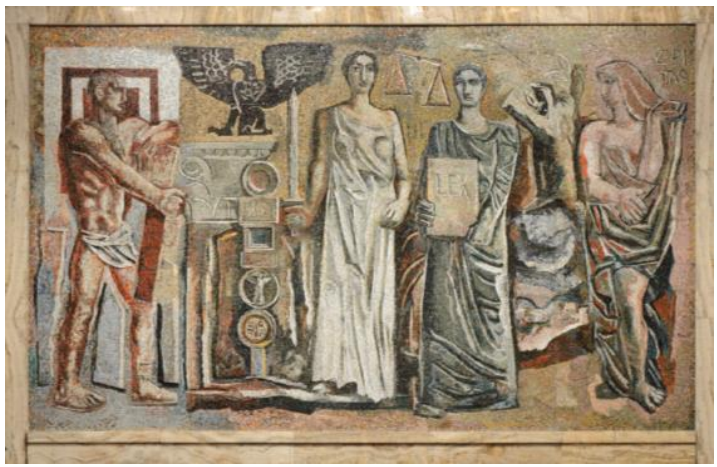

Fig 10. Example of photo-rectified image of a mosaic in the Corte d'Assise d'Appello by Sironi. 
In the case of flat-like objects, the acquisition of a distortion corrected image and its photo-rectification was sufficient (Fig. 10). The case of $3 \mathrm{D}$ objects required the acquisition of several frames and processing based on digital photogrammetry and laser scanning, as illustrated in the next sections.

\subsection{Photogrammetry for 3D artworks}

Three-dimensional artworks (mainly bas-reliefs and statues) required a 3D photogrammetric technique. Examples are the case of the wall paintings on curved support, statues, and basreliefs that did not allow the use of simpler photo-rectification methods.

3D photogrammetry allowed the reconstruction of texturized 3D models from a sequence of digital images taken from different points of view. For each artwork, an average of about fifteen frames was acquired, keeping the zoom locked and a low ISO value for a better quality of the photographs. Photos were all taken from different angles and with different inclinations, but all as equidistant as possible from the object in an ideal circular motion around it.

Data processing was carried out through Agisoft Metashape. The software can orient the images, generates a dense point cloud and a textured mesh, from which an orthophoto can be finally exported. An example of complete photogrammetric processing, including the different phases of workflow, is shown in Fig.s 11-14.
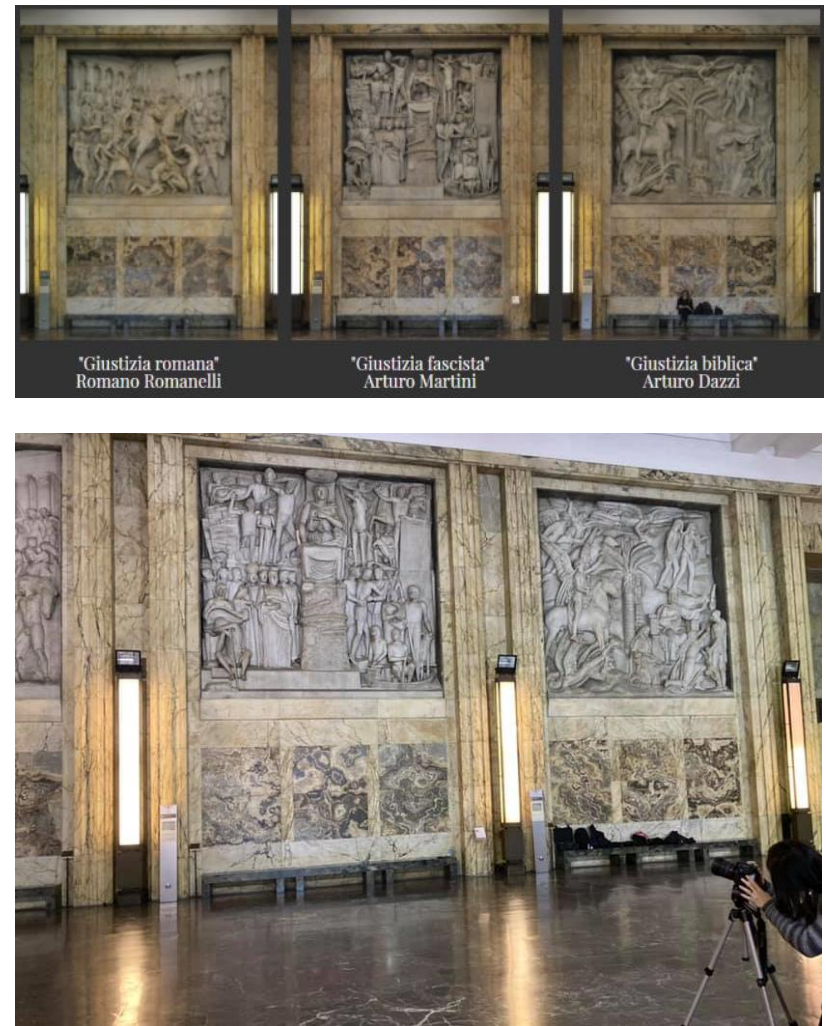

Fig. 11. Photogrammetric acquisition was carried out always using a tripod to achieve pictures with sufficient quality.

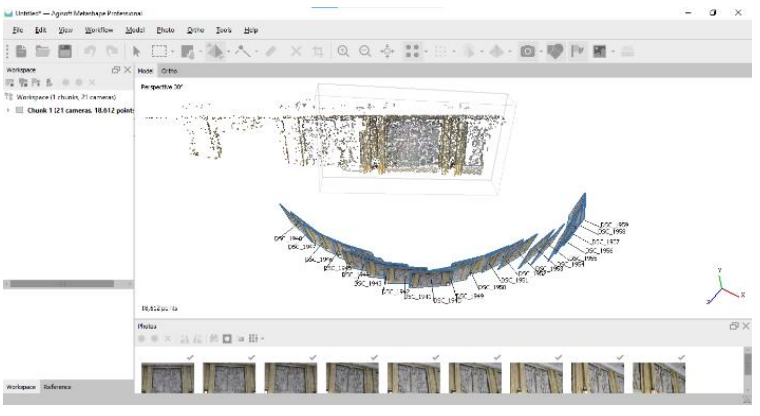

Fig 12. Results after image orientation.

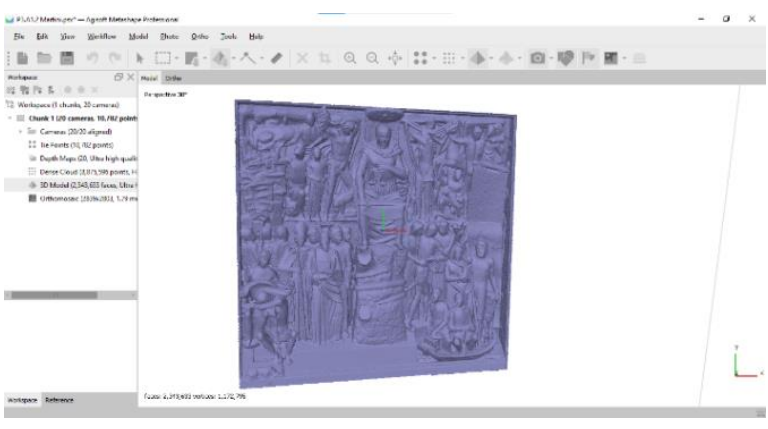

Fig 13. 3D mesh without texture (shaded).

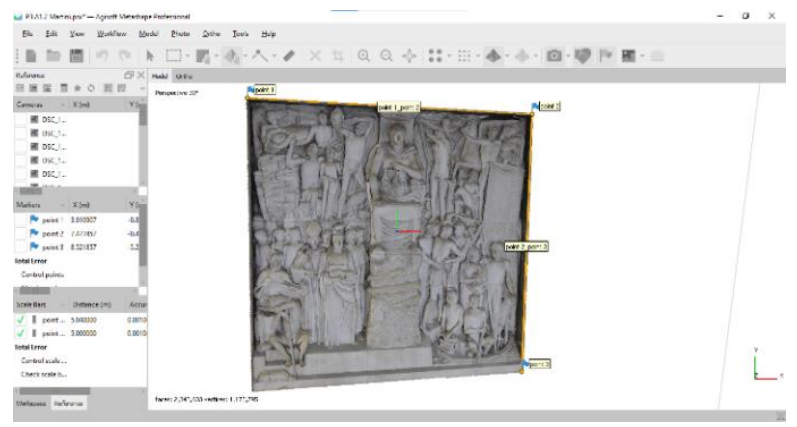

Fig 14. Textured mesh scaled using control points.

The final product is a 3D model useful for different purposes. The digital model can be used by conservators to carry out calculations, mapping of deteriorations, and other studies. The model can be exported in formats (obj, 3D pdf) that can be opened in free-of-charge software. Moreover, it is possible to upload the digital model in Sketchfab (www.sketchfab.com) and link it to the developed website, so that $3 \mathrm{D}$ models are freely available to any user.

In the case of wall paintings on a curved surface, therefore cases in which the three-dimensional model was only necessary to the above-mentioned scientific purposes, processing continued with the extraction of orthophotos and the publication on the website.

\subsection{Photo-rectification}

The only 2D artworks in the Palace are the mosaics: a big one placed inside the courtroom of the Corte d'Assise d'Appello (Fig. 10) created by Sironi, and nine smaller ones placed outside the classrooms above the door, designed by Santagata and Severini. 
As they do not feature a three-dimensional geometry, a photographic survey coupled with rectification techniques was sufficient. The images were processed through PTLens to remove the distortion generated by the lens mounted on the camera body. The program can automatically remove lens distortion if the model of the camera body and lens are both available in the correction database. One of the problems found in the use of this program was the overcorrection for images taken with a long zoom lens (i.e. very long focal lengths).

Photo rectification was carried out with Perspective Rectifier (Fig. 15), using vertical and horizontal lines that allow the calculation of the vanishing points. Then, the image can be converted into an orthogonal projection (rectified image) setting a width/height ratio. Two orthogonal measurements on the extreme points of the mosaic were used to the correct proportion of the mosaic.

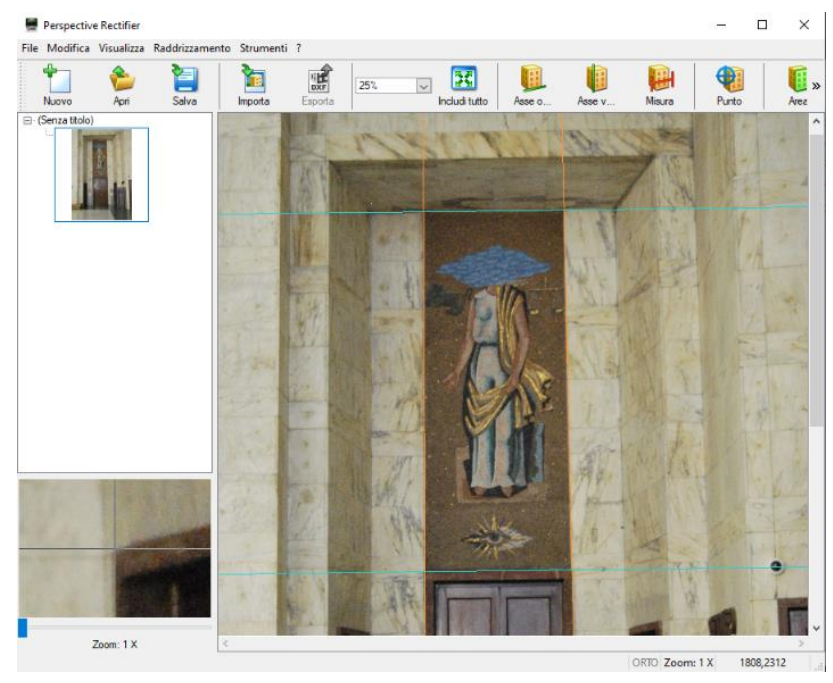

Fig 15. Gino Severini’s mosaic photo-rectification.

\subsection{Laser scanning measurements}

Laser scans were taken to properly scale photogrammetric reconstructions. Indeed, manual measurement through direct surveying tools (e.g., measuring tape) did not allow to measure some artworks placed at high levels, such as the bas-reliefs on the external facade placed at a height of about 15 meters above the floor. The use of a total station could be an alternative solution, but it requires the creation of witness sheets, which could take some time.

Moreover, the work was carried out on days when the court was regularly carrying out its function, making it necessary to minimize the data acquisition time of each artwork, optimizing time to capture the largest number of artifacts.

Using this approach, the authors were able to digitize 53 artworks (about half of the existing ones) in less than 3 working days. Fig. 16 shows some scans were imported into Faro Scene, in which distances (for photo-rectification projects) and 3D point coordinates were measured and used in photogrammetric projects.

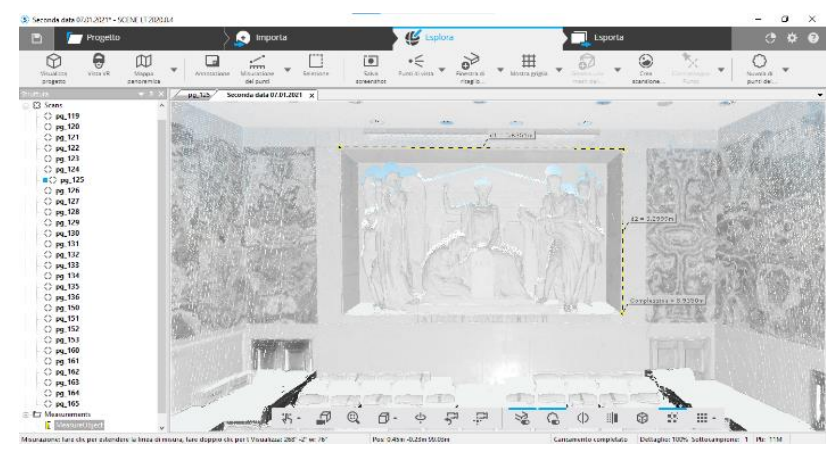

Fig 16. Example of laser scanning point cloud used to measure 3D coordinates and distances used in the photogrammetric projects.

\section{DEVELOPMENT OF THE WEBSITE}

The decision to develop a repository based on a website fulfills many objectives of the project. A section reserved for specialists (password protected) is used as support for the conservation of the artworks. At the same time, the re-appropriation and communication of the building as a museum is carried out through the public level of the website (https://scoprimipalazzodigiustizia.com/).

The website is at the moment available only in Italian. It offers simple access to citizens for its user-friendly interface. Moreover, it can be explored using multiple devices (computers, mobile phones, tablets).

The password-protected section is where management and conservation activities can take place. The specialist in conservation and the managers of the Palace can view and download the artworks' information, the preventive and programmed maintenance plan as well as download specific forms to be filled out for each intervention.

A direct naming convention allows immediate access to a shared folder. Artworks are named with their codes and authors (e.g., "P3.A1.3 Dazzi" for the work "Giustizia biblica" by Arturo Dazzi located in the first ambulatory of the third floor).

Each folder contains the digital files and the documentation related to the artwork: dxf or obj files according to the artwork type, context, and detailed photos of the inspections, and the ICCD schedule.

In this specific case, the creation of a website was the most appropriate solution, although it differs from traditional museum websites because the goal is not to provide an on-site visit. As already mentioned, the Palace of Justice carries out a particularly delicate task. It is a place intentionally inaccessible and open to the public on rare and special occasions. Although some guided tours were organized inside the building, for several years the building is accessible only for people passing security controls.

The development of a tool for the preservation of artworks was an opportunity to narrate the history of the Palace. The public level of the site is accessible to anyone. The user can discover the history of the Palace as a museum of the Thirties. It is designed to allow the re-appropriation of an asset that is present in the daily life of the city of Milan, whose artistic and historical importance remains mainly unknown. 
The following diagram illustrates the architecture of the website (Fig 17):

- Section I: dedicated to the overall context, including artistic, architectural, historical, and political aspects;

- $\quad$ Section II: reserved to artworks, their placement, their iconography, their vicissitudes, up to the single page of each one and their representation;

- $\quad$ Section III: reserved for custodians, conservators, and other authorized experts. It contains sensitive documents and for this reason, it is password protected.

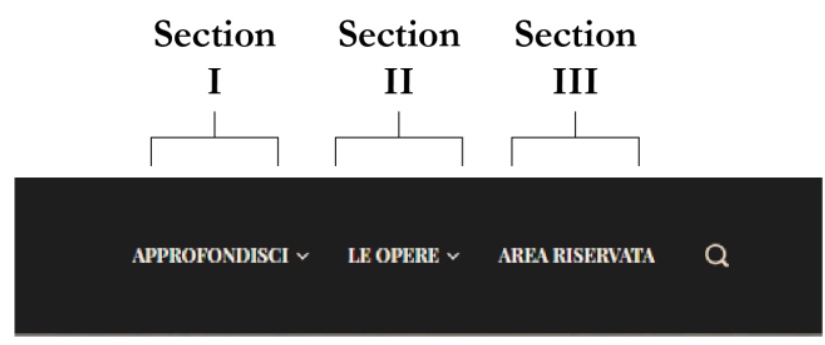

Fig 17. Website menus.

3D simplified models of the buildings show the location of the artworks, which can be explored also in virtual reality (Fig. 18).

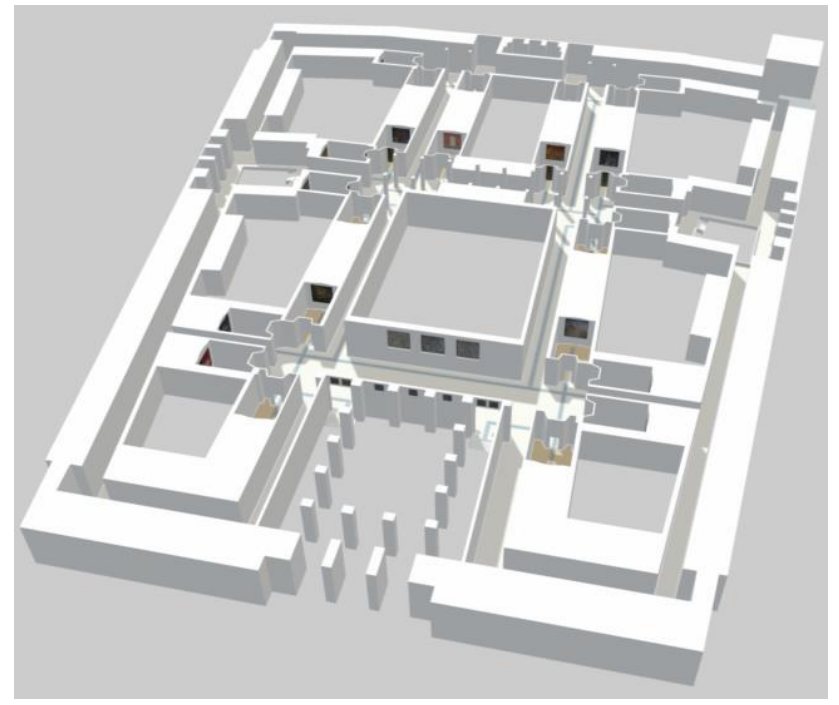

Fig 18. 3D model of a floor showing the location of the artworks.

The homepage of the website illustrates the history of the Palace with images, descriptions, and videos (Fig. 19). A questionnaire is available so that the user can play and know more about the palace (Fig. 20)

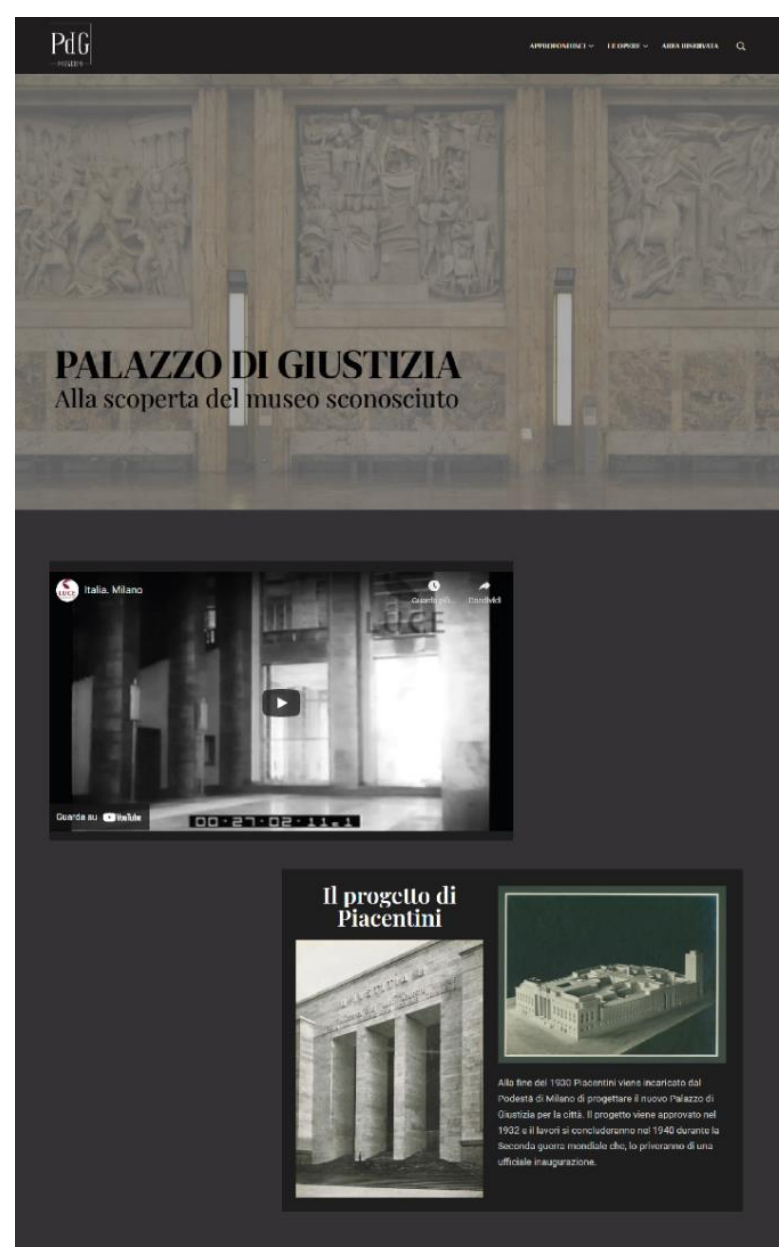

Fig 19. A part of the homepage of the website.

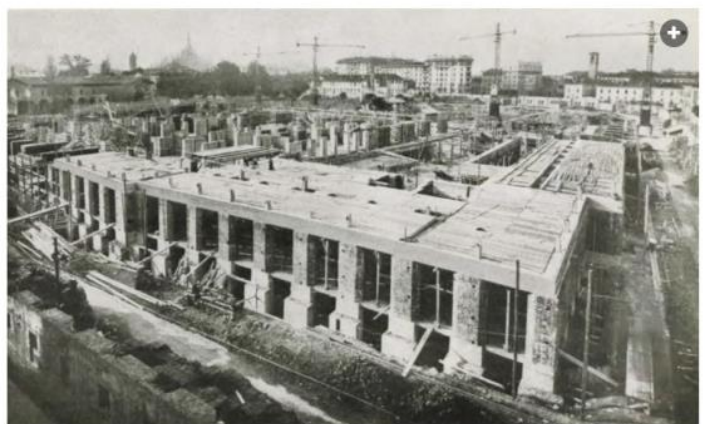

In quali anni è stato costruito il Palazzo?

1947-1952, dopo la Seconda Guerra Mondiale

1910-1915, prima della Prima Guerra Mondiale

1932-1940, a cavallo della Seconda Guerra Mondiale

$\checkmark$ Verifica

Fig. 20. Questionnaire about the palace. 
The homepage has also a section that describes the area and the demolitions necessary to build the palace (Fig. 21).

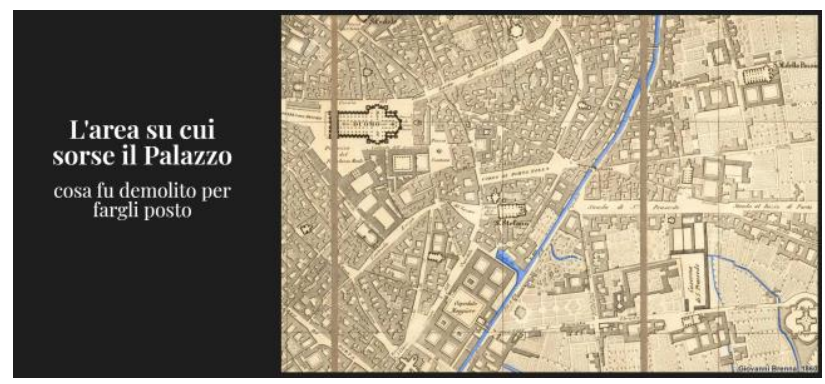

Fig. 21. Description of the area in which the palace was built.

The website also offers an overall view of the artworks, which cannot be obtained even with an onsite visit (Fig. 22).

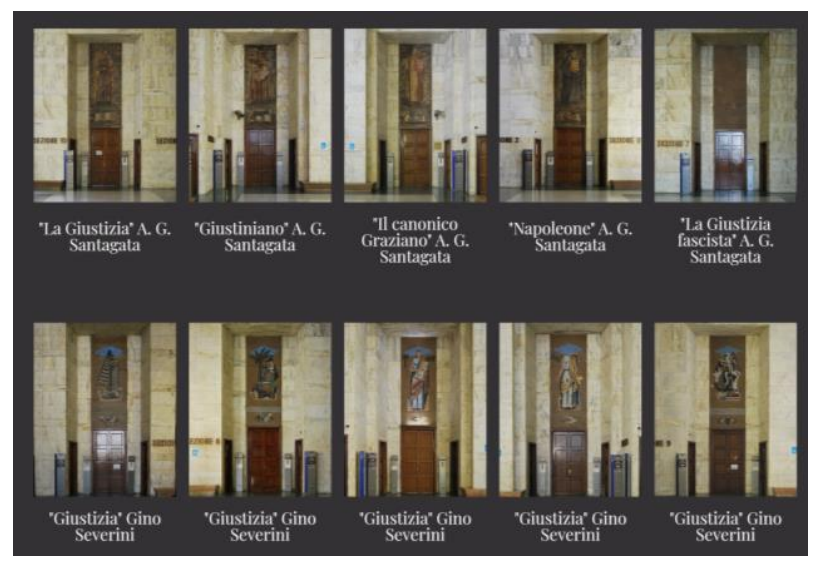

Fig. 22. Compiled image with the different mosaics.

3D models are also embedded in the open section of the website (Fig. 23). The website provides information about the creation date, author, concept, size and materials, and the location inside the building.

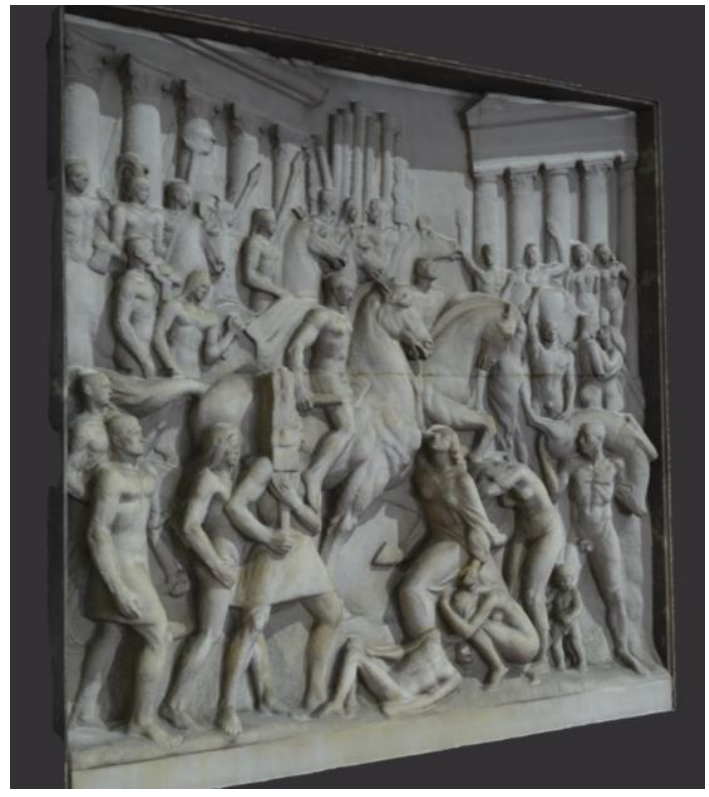

Fig. 23. Example of 3D model accessible using the website.

\section{CONCLUSIONS}

The need to develop a tool for the preservation of the artworks in the Palazzo di Giustizia has allowed studying the history of a symbolic place of Milan, which is now underestimated and poorly investigated. The development of the database and the narrative system required the cooperation of conservation and geomatics specialists.

There were some theoretical as well as practical issues in the proposed work, including a lack of knowledge about the Palace and the complex task of creating a system with both public and private sections for the protected nature of the building, and the management and organization of a large amount of different data. Therefore, the problem was not only a matter of creating a digital tool for the Palace's managers, but also the creation of new information that was stored on the website.

The continuous judicial activity represented a challenge because it limited access to some spaces. The limited accessibility resulted in the impossibility to complete the identification of all the artworks, some of which are mentioned by the available sources (documents). However, in some cases but it has not been possible to verify their effective presence within the Palace.

The on-site inspection and work allowed the digital survey of most artworks. Although for some of them it was not possible to perform complete digital documentation, it was possible to catalog them and produce preliminary representations. Future work will be necessary to integrate what is still missing. The platform and the website were implemented considering future integrations.

To conclude, the work allowed us to deepen the history of the Palace, highlighting some critical aspects of the information produced so far, and focusing on the relationship between the artworks and the Palace as a result of the conception of a single great project. The authors also tried to investigate all the aspects of which they were not fully aware, starting from the number of artworks, their artists, titles, iconographic subjects, and all the events that have seen them as protagonists, from censorship to demolitions.

Starting from the requirements to create a complete digital archive of the artworks, this project provided the opportunity to investigate aspects completely neglected until now, probably due to the building's weak reputation for its function and its deep relationship with the fascist regime.

Although it has not been possible to answer all questions and resolve all the problems, the work tackled some issues that were unexplored, resulting in a digital tool for the conservation and knowledge of the artworks in an unknown museum.

\section{REFERENCES}

Accetti C. E., La Giustizia e il suo Palazzo in Milano, Società Editrice Libraria, 1943

Amaturo M., Castellani P., Catalogare le opere d'arte, Istituto Centrale per il Catalogo e la Documentazione, MiBAC, 2006

Architettura: Rivista del Sindacato nazionale fascista architetti: Il palazzo di giustizia di Milano, Garzanti, Milano, 1942, XX Dossier I-II 
Barilli R. Anni Trenta. Arte e cultura in Italia. Catalogo della mostra (Milano, 1982), Mazzotta, 1999

Baldacci P., Borromeo D. L., Stringa N., Arturo Martini e il monumento per il Palazzo di Giustizia a Milano, FAI, 2018

Bernabò M., Bisanzio negli anni trenta del Novecento: il palazzo di Giustizia di Milano, in Arte Lombarda, Vol. 179/180, No. 1/2, 2017, pp. 146-155

Bologna G., Milano. Il Palazzo di Giustizia, Milano 1988

CNR, Milazzo M., Realini M., MT 472 Giustiniano libera lo schiavo (Carlo Carrà 1938). Indagini diagnostiche sui materiali ed il loro stato di conservazione, 07/06/472, 2007

CNR, Colombo C., Conti C., Bugini R., Realini M., MT 478 Mosè che detta le leggi (Siro Penagini, 1937). Studio dello stato di conservazione, 08/05/478, 2008

CNR, Colombo C., Realini M., Striova J., MT 490 Palazzo di Giustizia di Milano. Indagini su alcuni dipinti 09/12/490, 2009

Demirel B., Yuheng L., Shan L., Conservation of the courthouse of Milan, thesis at Politecnico di Milano, 2017

Fagone V., Carlo Carrà: la matita e il pennello, Skira, 1996

Fagone V., Ginex G., Sparagni T., Muri ai pittori. Pittura murale e decorazione in Italia 1930-50, Catalogo della mostra (Milano, 16 ottobre 1999-3 gennaio 2000) di

Galasso S., Il Palazzo di Giustizia di Milano: una Galleria d'Arte, 2014

Ganino M., Longani E., Note sulla scultura di Attilio Selva nel cortile d'onore del Palazzo di Giustizia di Milano, in Arte Lombarda No. 168/169, 2013, pp. 90-101

Germani G., La pittura murale italiana del Novecento. Sue peculiarità stilistiche e tecniche, thesis at Opificio delle Pietre Dure, 1983

Giolli R., Piccola inchiesta sul Palazzo di Giustizia, in Casabella-Costruzioni, november 1942

Lettera del Primo Presidente della Corte d'Appello al Podestà Gallarati Scotti circa le opere pittoriche, 5.08.1939, dossier 1939_10_1942, Cittadella degli Archivi, Milan archive

Mancinelli M. L., Gli standard catalografici dell'Istituto Centrale per il Catalogo e la Documentazione, in Le voci, le opere e le cose. La catalogazione dei beni culturali demoetnoantropologici, MiBACT, ICCD, 2018, pp. 279-301

Maulsby L. M., The Representation of Fascist Justice in Marcello Piacentini's Palace of Justice, Milan, 1932-1940, Journal of the Society of Architectural Historians, Vol. 73, No. 3 (September 2014), pp. 312-327

Notifica atto decisionale copertura provvisoria di alcune decorazioni pittoriche, 1.07.1940, dossier 1939_10_1942, Cittadella degli Archivi, Milan archive

Notizie sul Palazzo di Giustizia di Milano in Case d'oggi, num. 2, febbraio 1941, pp. 25- 34 e 53
Pacini P., I sei volti della giustizia. Gino Severini al Palazzo di Giustizia di Milano, in Art Dossier, 89 (aprile 1994), pp. 32-35

Pertile F., Arti plastiche e figurative nel Palazzo di Giustizia di Milano, in La rivista illustrata del Popolo d'Italia, October 1939, pp. 34-43

Rilievi del Primo Presidente della Corte d'Appello circa le opere pittoriche, 22.07.1939, dossier 1939_10_1942, Cittadella degli Archivi, Milan archive

Risposta dell'arch. Marcello Piacentini al podestà Gallarati Scotti, 2.08.1939, dossier 1939_10_1942, Cittadella degli Archivi, Milan archive

Santoro A., 2021. Un museo sconosciuto: il Palazzo di Giustizia di Milano. Uno strumento per la valorizzazione $e$ la conservazione preventiva e programmata delle opere d'arte. Master thesis at Politecnico di Milano.

Siena F., Studio e restauro del dipinto murale di Ottavio Steffenini (1937) nel Palazzo di Giustizia a Milano. Sperimentazione per la riduzione dei Sali solubili, thesis at Opificio delle Pietre Dure, 2016-17

Torriano P., Il Palazzo di Giustizia a Milano, L'illustrazione italiana, num. 44, ottobre 1939 